\title{
Effect of very early intervention with metoprolol on myocardial infarct size
}

\author{
D McC BOYLE, J M BARBER, E L MCILMOYLE, K S SALATHIA, A E EVANS, G CRAN, \\ J H ELWOOD, R G SHANKS
}

From the Department of Cardiology, Ulster Hospital, Belfast, and Queen's University, Belfast

SUMMARY All patients with a presumptive diagnosis of myocardial infarction, who were seen within six hours of the onset of symptoms and had no reason for exclusion, were considered for entry into a trial to compare the effects of metoprolol and placebo on creatine kinase MB isoenzyme release. The trial was randomised and double blind. The median time from onset of symptoms to receiving trial drug was just under two hours. Two hundred and four patients (of whom 120 had myocardial infarction) received metoprolol and 187 (of whom 105 had myocardial infarction) received placebo.

Infarct size was estimated semiquantitatively using cumulative release of the cardiospecific isoenzyme, creatine kinase MB. Mean creatine kinase MB isoenzyme was less in patients who received metoprolol, but the reduction did not achieve statistical significance. Clinical problems related to early intravenous metoprolol were uncommon.

Intervention with beta adrenoceptor antagonists in patients who have sustained a myocardial infarction is generally accepted to reduce mortality when given some days after the acute event. ${ }^{1-3}$ Few studies, however, have looked at the effect of very early intervention with beta adrenergic antagonists in the acute phase of myocardial infarction. Since patients with suspected acute myocardial infarction at the Ulster Hospital are usually seen by our mobile coronary care unit, we were in a unique position to assess the effect of early intervention. A theoretical benefit of early beta adrenergic blockade is reduction of infarct size. $^{45}$ We report a study designed to test this hypothesis using the cardioselective beta adrenergic blocking drug metoprolol. Metoprolol has no partial agonist activity and no membrane stabilising activity. It has been used with safety during the acute stages of infarction. ${ }^{6}$

\section{Patients and methods}

From 1 June 1979 to 31 January 1981, all patients with a presumptive diagnosis of myocardial infarction were considered for inclusion in the trial. Patients were excluded if: (1) there was a delay of more than six hours after the onset of symptoms; (2) there were clinical contraindications to the use of beta adrenergic

Accepted for publication 26 November 1982 blocking drugs, that is heart block greater than first degree, clinical pulmonary oedema, cardiogenic shock, bradycardia with hypotension, or agonal rhythm; (3) the initial rhythm was ventricular fibrillation; (4) they had received a beta adrenergic blocking drug or antiarrhythmic drug, other than digitalis, within the 48 hours before admission.

The study was double blind and patients were randomly allocated to placebo or active drug in balanced blocks of 100 . Since patients were seen in an acute situation, some were admitted to the trial on more than one occasion. In this event, only the data relating to the initial admission were considered in the analysis. In addition, several ampoules were accidentally broken or wasted.

Intravenous trial drug, either $15 \mathrm{mg}$ metoprolol or an equal volume of saline labelled in a similar manner, was given over a period of three minutes as soon as possible after making the presumptive diagnosis. Providing that the systolic blood pressure did not fall below $90 \mathrm{mmHg}$ and that second or third degree heart block did not occur, the intravenous injection was followed, 10 minutes later, by half a tablet orally, either $15 \mathrm{mg}$ metoprolol or placebo, and at six-hourly intervals during the first $\mathbf{4 8}$ hours in hospital.

Myocardial infarction was diagnosed where any one of seven blood samples taken during the first 72 hours in hospital contained 15 or more international units per litre (IU/l) of creatine kinase MB isoenzyme. The 
only exceptions were patients who died before blood sampling was completed, but in whom the diagnosis of infarction was indubitable from electrocardiographic and clinical history. At the end of the first $\mathbf{4 8}$ hours in hospital, trial drug, either metoprolol $100 \mathrm{mg}$ or placebo, was prescribed twice daily for one year only if the patient had had a myocardial infarction. Informed verbal approval to participate in the study was obtained from each patient $\mathbf{4 8}$ hours after admission to hospital. Infarct size was assessed by measurement of creatine kinase $M B$ isoenzyme release. This isoenzyme is cardiospecific and, unlike creatine phosphokinase, is unaffected by intramuscular injections or by defibrillation. It has been shown to be an appropriate enzyme for estimation of infarct size. ${ }^{78}$ Blood was taken from each patient at eight hourly intervals during the first $\mathbf{4 8}$ hours in hospital; at $8 \mathrm{am}$, $4 \mathrm{pm}$, and 12 midnight. On the morning following the sixth sample, a further sample was taken to detect late infarction or an extension of infarction. Creatine kinase $M M$ isoenzyme was estimated using column chromatography. The serum sample was added to a column of buffered "Sephadex". Creatine kinase MM isoenzyme was eluted using a quantity of the same buffer. The buffer was changed to a higher $\mathrm{pH}$, to elute the creatine kinase $\mathrm{MB}$ isoenzyme and it was measured using an ultraviolet kinetic method. 9 The amount of creatine kinase MB isoenzyme released, expressed as IU/1, was calculated using a modification of Sobel et al.'s method, ${ }^{10}$ according to the following equation:

$$
\text { Enzyme released }=E(T)+k d \int_{0}^{T} E(t) d t
$$

where $E(t)=$ enzyme level $(I U / l)$ at time $t$,

$t$ = time after onset of symptoms (hours),

$\mathrm{T}=$ time of sample $\mathrm{CK} M \mathrm{MB}$ level equals zero

for the first time after peak sample CKMB level has been achieved, otherwise, $=$ time of last available sample;

kd = dissociation constant $=0.095 \mathrm{IU} / \mathrm{h}^{8}$;

the area under the graph of $E(t), \int_{0}^{T} E(t) d t$, is approximated by

$$
\sum_{i=1}^{7} 1 / 2\left[E\left(t_{i}-1\right)+E\left(t_{i}\right)\right] \Delta t_{i}
$$

where $t_{0}=0, t_{1}, \ldots, t_{7}$ are the sampling times,

$$
E\left(t_{0}\right)=0 \text { and } \Delta t_{i}=t_{i}-t_{i-1} \text {, }
$$

when all seven samples are available; the formula is easily modified for less than seven samples. The above calculations were performed for all patients with at least five sample values available.

The design of the trial required comparison of enzyme release in the total patient group, and also in
Table 1 Admission characteristics of patients

\begin{tabular}{lrr}
\hline & Metoprolol & Placebo \\
\hline Total number of patients & 204 & 187 \\
Men & $140(69 \%)$ & $136(73 \%)$ \\
Women & $64(31 \%)$ & $51(27 \%)$ \\
Under 65 years & $144(71 \%)$ & $129(60 \%)$ \\
Over 65 years & $60(29 \%)$ & $58(31 \%)$ \\
With previous angina & $101(50 \%)$ & $87(47 \%)$ \\
With previous myocardial infarction $51(25 \%)$ & $51(27 \%)$ \\
With previous hypertension & $24(12 \%)$ & $25(13 \%)$ \\
Cigarette smokers & $85(42 \%)$ & $79(42 \%)$ \\
\hline
\end{tabular}

the following specified subgroups, depending on: (A) interval from onset of symptoms to intervention $(<2 \overrightarrow{0}$ hours or $\geqslant 2$ hours); (B) age ( $\leqslant 65$ years or $>65$ years); (C) initial heart rate $\left(>100 /\right.$ minute, $81-100 /$ minute, or $N_{0}$ $\leqslant 80 /$ minute); (D) site of infarction (anterior or inferior).

The size of the trial was based on an expected ${ }_{7}^{-}$ reduction of enzyme release in the order of $25 \%$ in patients with infarction. 5 It was estimated that $220 \mathrm{\rho}$ patients with myocardial infarction were needed and $\overrightarrow{0}$ that the trial should stop as soon as it was known thato at least 220 patients with myocardial infarction were ${ }^{\omega}$ included. Since there is a delay in confirming theo diagnosis of infarction, 225 patients with myocardial s infarction were entered.

\section{Results}

Three hundred and ninety-one patients received trial drug. Of these, 204 received metoprolol and 187 placebo. The difference in the group sizes is a result of the method of randomisation used, the admission of patients to the study more than once, and the accidental loss of a small number of ampoules: There were no 3 significant differences between the two groups in terms of their admission characteristics (Table 1). More than two thirds of the patients in each group were men, and more than two thirds were aged 65 응 years or less. The median delay time in each group was just under two hours. Myocardial infarction was?confirmed in 120 of the 204 patients who received o metoprolol (59\%) and in 105 of the 187 patients who were given placebo (56\%). The study failed to show that metoprolol caused a reduction in the proportion $w$ of patients who developed a myocardial infarction.

ENZYME RELEASE

Enzyme release was estimated in patients with five of more recorded values of creatine kinase $M B$ isoen $\frac{T}{0}$ zyme. It was possible to do this in 115 patients givenp metoprolol and in 96 patients given placebo. The mean amount of enzyme released was compared in the two groups (Table 2). It was 437 and 507 IU/1 in the 
metoprolol and placebo groups, respectively, representing an overall reduction in enzyme release of $14 \%$. The value of $p$ lay between 0.05 and $0 \cdot 1$. The reduction was not, therefore, statistically significant.

Enzyme release was studied in patient subgroups. Two subgroups of patients showed statistically significant reduction of enzyme release after administration of metoprolol-those aged 65 years or less and those who had an inferiorly sited myocardial infarction. Eighty patients aged 65 years or less received metoprolol and had a mean release of $421 \mathrm{IU} / \mathrm{l}$. Sixty-five patients aged 65 years and under received placebo and had a mean release of $543 \mathrm{IU} / 1$. This represents a reduction in enzyme release of $22 \%$ in patients of this age group given metoprolol compared with controls. This difference was statistically highly

Table 2 Mean enzyme release in patients with myocardial infarction

\begin{tabular}{|c|c|c|c|c|c|c|c|}
\hline \multirow[b]{2}{*}{$\begin{array}{l}\text { All patients with estimable infarct size } \\
\text { Delay time less than two hours } \\
\text { Delay time two hours or more } \\
\text { Patients with anterior infarction } \\
\text { Patients with inferior infarction } \\
\text { Age } 65 \text { years or less } \\
\text { Over } 65 \text { years } \\
\text { Heart rate over } 100 / \text { minute† } \\
\text { Heart rate } 81-100 / \text { minute† } \\
\text { Heart rate } 80 / \text { minute or less } \$ \$\end{array}$} & \multirow{2}{*}{$\begin{array}{l}\begin{array}{l}\text { No. of patients } \\
\text { given } \\
\text { metoprolol }\end{array} \\
115 \\
58 \\
57 \\
69 \\
44 \\
80 \\
35 \\
15 \\
30 \\
68\end{array}$} & \multicolumn{2}{|c|}{$\begin{array}{l}\text { Enzyme released } \\
\text { SEM } \\
(I U / l)\end{array}$} & \multirow{2}{*}{$\begin{array}{l}\text { No. of patients } \\
\text { given placebo } \\
96\end{array}$} & \multicolumn{2}{|c|}{$\begin{array}{l}\text { Enzyme released } \\
\text { SEM } \\
(I U / l)\end{array}$} & $\begin{array}{l}\% \text { reduction } \\
\text { in mean enzyme } \\
\text { release } \\
14 \% \star\end{array}$ \\
\hline & & $\begin{array}{l}437 \\
495 \\
378 \\
476 \\
383 \\
421 \\
474 \\
400 \\
502 \\
421\end{array}$ & $\begin{array}{l}32 \cdot 2 \\
54 \cdot 0 \\
33 \cdot 5 \\
48 \cdot 7 \\
33 \cdot 2 \\
39 \cdot 8 \\
54 \cdot 7 \\
56 \cdot 6 \\
87 \cdot 4 \\
36 \cdot 5\end{array}$ & & $\begin{array}{l}507 \\
554 \\
441 \\
498 \\
506 \\
543 \\
431 \\
495 \\
549 \\
481\end{array}$ & $\begin{array}{r}32 \cdot 9 \\
46 \cdot 1 \\
44 \cdot 0 \\
43 \cdot 8 \\
49 \cdot 4 \\
42 \cdot 1 \\
48 \cdot 7 \\
105 \cdot 1 \\
56 \cdot 7 \\
42 \cdot 2\end{array}$ & $\begin{array}{l}14 \% \star \\
11 \% \\
14 \% \\
4 \% \\
24 \% \star \star \\
22 \% \star \star \star \\
-9 \% \\
19 \% \\
9 \% \\
12 \%\end{array}$ \\
\hline
\end{tabular}

tt tests were used except for heart rates of 81 to 100 and for those over 100/minute Mann-Whitney tests were carried out.

$\neq \emptyset$ Two patients who were given metoprolol and one patient given placebo had initial heart rates recorded, but these records were subsequently lost.

$$
\begin{aligned}
& { }^{\star} \mathrm{p} \text { lies between } 0.05 \text { and } 0.1 \\
& { }_{\star} \mathrm{p} \text { lies between } 0.01 \text { and } 0.05 \\
& \star \star \star \mathrm{p} \text { lies less than } 0.01
\end{aligned}
$$

Table 3 Reasons for withdrawal of trial drug in patients with myocardial infarction

\begin{tabular}{llllll}
\hline & $\begin{array}{l}\text { No. of patients with } \\
\text { myocardial infarction }\end{array}$ & $\begin{array}{l}\text { X-ray evidence } \\
\text { of pulmonary oedema }\end{array}$ & $\begin{array}{l}\text { Systolic blood } \\
\text { pressure } \leqslant 80 ~ m m H g\end{array}$ & $\begin{array}{l}\text { Heart block } \\
\geqslant 2 \text { md }^{\circ}\end{array}$ & Other reasons \\
\hline $\begin{array}{l}\text { Metoprolol } \\
\text { Placebo }\end{array}$ & 120 & $17(14 \%)$ & $11(9 \%)$ & $6(5 \%)$ & $11(9 \%)$ \\
\hline
\end{tabular}

One patient receiving metoprolol had both pulmonary oedema and hypotension; two patients receiving placebo had both pulmonary oedema

\begin{tabular}{|c|c|c|c|c|c|}
\hline & Definition of patient group & $\begin{array}{l}\text { No. given } \\
\text { beta-blocker }\end{array}$ & $\begin{array}{l}\text { No. given } \\
\text { placebo }\end{array}$ & $\begin{array}{l}\% \text { reduction } \\
\text { in enzymes }\end{array}$ & Significance \\
\hline Yusuf et al. ${ }^{16}$ & $\begin{array}{l}\text { Patients with ECG evidence of } \\
\text { myocardial infarction-total } \\
\text { delay time } \leqslant 12 \text { hours; using } \\
\text { creatine kinase } M B \text { isoenzyme }\end{array}$ & $\begin{array}{l}72 \\
\text { (atenolol) }\end{array}$ & 63 & 32 & $\begin{array}{l}\text { Statistical } \\
\text { signi ficance } \\
\text { at } p<0.05\end{array}$ \\
\hline Peter et al. ${ }^{5}$ & $\begin{array}{l}\text { Patients } 65 \text { years or under } \\
\text { with ECG evidence of myocardial } \\
\text { infarction-total delay time } \leqslant 4 \\
\text { hours; using creatine kinase }\end{array}$ & $\begin{array}{l}15 \\
\text { (propranolol) }\end{array}$ & 19 & 25 & $\begin{array}{l}\text { Statistical } \\
\text { significance } \\
\text { at } \mathrm{p}<0.05\end{array}$ \\
\hline Jurgensen et al. ${ }^{17}$ & $\begin{array}{l}\text { Patients aged }<66 \text { years with } \\
\text { ECG evidence of myocardial infarction } \\
\text { - total delay time } \leqslant 12 \text { hours; using } \\
\text { creatine kinase }\end{array}$ & $\begin{array}{l}42 \\
\text { (alprenolol) }\end{array}$ & 43 & 42 & $\begin{array}{l}\text { Statistical } \\
\text { significance } \\
\text { at } p<0.05\end{array}$ \\
\hline Hjalmarson et al. ${ }^{15}$ & $\begin{array}{l}\text { Patients aged } 40 \text { to } 74 \text { years with } \\
\text { ECG evidence of myocardial infarction } \\
\text { - total delay time } \leqslant 12 \text { hours; using } \\
\text { lactate dehydrogenase }\end{array}$ & $\begin{array}{l}427 \\
\text { (metoprolol) }\end{array}$ & 475 & 15 & $\begin{array}{l}\text { Statistical } \\
\text { significance } \\
\text { at } p<0.05\end{array}$ \\
\hline $\begin{array}{l}\text { Metoprolol study, } \\
\text { Ulster Hospital }\end{array}$ & $\begin{array}{l}\text { Patients with creatine kinase MB } \\
\text { isoenzyme } \geqslant 15 \text { IU } / 1 \text {-total delay } \\
\text { time } \leqslant 6 \text { hours }\end{array}$ & $\begin{array}{l}115 \\
\text { (metoprolol) }\end{array}$ & 96. & 14 & $\begin{array}{l}\text { p lay between } \\
0.05 \text { and } 0.1\end{array}$ \\
\hline
\end{tabular}
and hypotension.

Table 4 Enzyme release studies 
significant $(p<0.01)$ (Table 2). Forty-four patients in the metoprolol group had inferior infarction. The mean release of creatine kinase $M B$ isoenzyme was $383 \mathrm{IU} / 1$. Thirty-eight patients in the placebo group, and who had inferior infarction, had a mean release of $506 \mathrm{IU} / \mathrm{l}$. This represents a reduction in infarct size of $24 \%$ and was statistically significant $(p<0 \cdot 05)$. In each of the subgroups about two thirds of the patients were 65 years or less, so that reduction in infarct size in patients with inferior infarction appeared to be independent of age. In the other subgroups examined, no significant reduction in creatine kinase MB isoenzyme was found (Table 2).

\section{ACUTE CLINICAL RESPONSE}

Clinical problems related to early intravenous metoprolol were uncommon. Trial drug was stopped in hospital because of possible adverse effects in $37 \%$ of patients with myocardial infarction after receiving metoprolol and in $30 \%$ of those receiving placebo. The difference is not statistically significant. The incidence of possible adverse reactions which led to withdrawal of the trial drug is given in Table 3. Heart failure, defined as radiological evidence of interstitial or acute alveolar oedema, occurred in $14 \%$ of patients irrespective of their receiving metoprolol or placebo. Severe hypotension occurred in $9 \%$ of patients receiving metoprolol and in $6 \%$ of those given placebo. Overall blood pressure level tended to be lower in patients given metoprolol. Six hours after receiving metoprolol, mean systolic blood pressure was 115 $\mathrm{mmHg} \pm 1.9(\mathrm{SEM})$ in those receiving metoprolol and $126 \mathrm{mmHg} \pm 2.0$ in those receiving placebo, a highly significant result (t test $p<0.01$ ). Second degree or more severe atrioventricular heart block occurred more frequently in the placebo group of patients.

Results of long term follow-up will be reported at a later date.

\section{Discussion}

All methods of estimating infarct size in living patients are imprecise. A possible criticism of enzyme release estimation is that intervention may alter release of enzymes by mechanisms other than reduction of the size of infarction. Whether beta adrenergic blockade alters the amount of myocardial enzyme released into the blood stream irrespective of infarct size has not been studied, as far as we are aware. Beta adrenergic blockade does not appear to influence the handling of creatine kinase by the body after its release from the heart, ${ }^{11}$ though this is disputed by Cairns and Klassen ${ }^{12}$ who reported that propranolol may produce an artefactual reduction in infarct size using creatine kinase measurement in dogs. Using creatine kinase MB isoenzyme, Grande et al.$^{13}$ found a close correlation with histological infarct size in humans. Modification of enzyme release by beta adrenergic blockade appears to parallel other indirect estimates of infarct size, such as electrocardiographic mapping, ${ }^{14}$ and we believe it is valid to use creatine kinase MB isoenzyme release as an indirect measurement of infarct size.

In studies of this kind, the most relevant finding is that applicable to the entire group, rather than to subgroups. In our study, there was an apparent reduction of creatine kinase $\mathrm{MB}$ isoenzyme release of $14 \%$. The value of $p$ lay between 0.05 and $0 \cdot 1$, so that statistical significance was not achieved. This finding must be looked at in the context of other studies in which a beta adrenergic blocking drug is given intravenously in the early hours after myocardial infarction.

Decisions on the benefit of clinical intervention are frequently based on pooled data of available series. Bias is introduced in pooling if negative studies are not available for comparison. Our results are consistent with other published studies, ${ }^{515^{-17}}$ suggesting a true reduction of enzyme release (Table 4).

Subgroup analysis, even when the subgroups are defined at the outset of the study, increases the chance of spurious significant differences but does give a basis for hypotheses to be tested. Our results suggest that a reduction in enzyme release is more likely to occur in the younger age group. This is in contrast to Hjalmarson et al.'s study. ${ }^{15}$ The effect of age in all studies needs careful consideration. Our other finding of reduction of enzyme release in inferior as opposed to anterior infarction is unexpected, as both Tommasini et al. ${ }^{11}$ and the authors of the practolol study ${ }^{18}$ suggest a benefit in patients with anterior infarction given beta adrenergic blockade. The influence of infarct site deserves further consideration.

Grande $e t$ al.$^{13}$ showed that infarct size was a relatively unimportant determinant of in-hospital mortality, but that it provides a reliable indication of long term prognosis in acute myocardial infarction. The clinical importance of reduction of infarct size will be difficult to prove, since a large number of patients would be involved, and the compounding effect of secondary prevention by long term beta adrenergic blockade would have to be eliminated.

We wish to thank the Department of Health and Social Services, and Astra Pharmaceuticals for their financial support.

\section{References}

$1 \beta$-Blocker Heart Attack Study Group. The $\beta$-Blocker Heart Attack Trial. FAMA 1981; 246: 2073-4.

2 Norwegian Multicentre Study Group. Timolol-induced 
reduction in mortality and reinfarction in patients surviving acute myocardial infarction. $N$ Engl F Med 1981; 304: 801-7.

3 Hansteen V, Møinichen E, Lorentsen E, et al .One year's treatment with propranolol after myocardial infarction; preliminary report of Norwegian multicentre trial. $\mathrm{Br}$ Med f 1982; 284: 155-60.

4 Maroko PR, Kjekshus JK, Sobel BE, et al. Factors influencing infarct size following experimental coronary artery occlusions. Circulation 1971; 43: 67-82.

5 Peter T, Norris RM, Clarke ED, et al. Reduction of enzyme levels by propranolol after acute myocardial infarction. Circulation 1978; 57: 1091-5.

6 Malek I, Waagstein F, Hjalmarson A, Holmberg S, Swedberg K. Hemodynamic effects of the cardioselective $\beta$-blocking agent metoprolol in acute myocardial infarction. Acta Med Scand 1978; 204: 195-201.

7 Roberts R, Henry PD, Witteveen SAGJ, Sobel BE. Quantification of serum creatine phosphokinase isoenzyme activity. Am 7 Cardiol 1978; 33: 650-4.

8 Grande P, Naestoft J, Christiansen C. An easy and reliable estimation of acute myocardial infarct size from serum CK-MB measurements. Eur F Cardiol 1980; 11: 71-7.

9 Recommendations of the German Society for Clinical Chemistry. F Clin Chem Biochem 1977; 15: 225-40.

10 Sobel BE, Bresnahan GF, Shell WE, Yoder RD. Estimation of infarct size in man and its relation to prognosis. Circulation 1972; 46: 640-8.

11 Tommasini G, Berra R, Oddone A, et al. Reduction of infarct size in patients by early administration of propranolol, hyaluronidase, nitroglycerin, acetylsalicylate. 8th European Congress of Cardiology 1980; abstract 1568: 131 .

12 Cairns JA, Klassen GA. The effect of propranolol on canine myocardial CPK distribution space and rate of disappearance. Circulation 1977; 56: 284-8.

13 Grande P, Hansen BF, Christiansen C, Naestoft J. Acute myocardial infarct size estimated by serum CK-MB determinations: clinical accuracy and prognostic relevance utilizing a practical modification of the isoenzyme approach. Am Heart f 1981; 101: 582-6.

14 Yusuf S, Lopez R, Maddison A, et al. Value of electrocardiogram in predicting and estimating infarct size in man. Br Heart f 1979; 42: 286-93.

15 Hjalmarson $\AA$, Elmfeldt D, Herlitz J, et al. Effect on mortality of metoprolol in acute myocardial infarction. Lancet 1981: ii: 823-7.

16 Yusuf S, Ramsdale D, Peto, R, et al. Early intravenous atenolol treatment in suspected acute myocardial infarction. Lancet 1980; ii: 273-6.

17 Jürgensen HJ, Frederiksen J, Hansen DA, PedersenBjergaard $\mathrm{O}$. Limitation of myocardial infarct size in patients less than 66 years treated with alprenolol. $\mathrm{Br}$ Heart $\mathcal{F}$ 1981; 45: 583-8.

18 Green KG, Chamberlain DA, Fulton RM, et al. Improvement in prognosis of myocardial infarction by long-term beta-adrenoceptor blockade using practolol. Br Med F 1975; iii: 735-40.

Requests for reprints to Dr D McC Boyle, Cardiac Unit, Ulster Hospital, Dundonald, Belfast BT16 $\mathrm{ORH}$, Northern Ireland. 